\title{
Oral hygiene and $H$. pylori infection in the elderly
}

Kiyoshi Fujisawa ${ }^{1}$, Yutaka Takata ${ }^{1}$, Toshihiro Ansai ${ }^{2}$, Kazuo Sonoki ${ }^{1}$, Inho Soh ${ }^{2}$, Akihiro Yoshida ${ }^{2}$, Sumio Akifusa $^{2}$, Shuji Awano ${ }^{2}$, Tomoko Hamasaki ${ }^{2}$, Tomoko Ohsumi ${ }^{3}$, Sen Higshi ${ }^{3}$, Yukiko Koga ${ }^{3}$, Tatsuji Nishihara ${ }^{4}$ and Tadamichi Takehara ${ }^{2}$ ( ${ }^{1}$ Division of General Internal Medicine, ${ }^{2}$ Division of Community Oral Health Science, ${ }^{3}$ Division of Applied Pharmacology and ${ }^{4}$ Division of Infections and Molecular Biology, Kyushu Dental College)

The oral cavity is thought to be a reservoir for Helicobacter pylori ( $H$. pylori), and is related to $H$. pylori infection. However, the relationship between oral hygiene and $\mathrm{H}$. pylori infection is unclear. The aim of this study is to investigate the relationship between $\mathrm{H}$. pylori infection and oral care. A total of 231 individuals (116 males, 115 females), who enrolled at two colleges for the elderly in Kitakyushu city, responded to a questionnaire, and underwent oral and medical examinations. H. pylori infection status was determined by the measurement of serum anti-H. pylori immunoglobulin G (IgG) antibody. The individuals who had undergone gastrectomy or eradication therapy for $H$. pylori, and those with two teeth or less remaining, were excluded. A total of 206 individuals were ultimately enrolled in the study. H. pylori-seropositive individuals numbered $134(65.0 \%)$. H. pylori infection tended to be associated with sex $(p=0.06)$, maximum of attachment loss $\geq 7 \mathrm{~mm}(\mathrm{p}=0.07)$ and daily frequency of toothblushing $(p=0.053)$ by univariate analysis. By multivariate analysis, the odds ratio for individuals who performed toothbrushing 3 times or more daily for $\mathrm{H}$. pylori infection was 0.40 (95\% confidence interval 0.15-0.98), in comparison with those who performed toothbrushing once daily or not at all, after adjustment for age and kind of work. It is possible that frequent toothbrushing can decrease the risk of H. pylori infection in elderly persons.

\section{Loop-mediated Isothermal Amplification（LAMP）法を用いた Actinobacillus actinomycetemcomitans の迅速検出}

\section{○大澤 良·吉田 明弘·永島 志織·安細 敏弘·竹原 直道}

九歯大·フロンティア

近年新しい遺伝子増幅法として Loop-mediated Isothermal Amplification (LAMP) 法が (株) 栄研化学より開 発された。本法は PCR 法と比較して，増幅効率及び特異性が非常に高いという特徴を有する．本研究では LAMP 法 を用いて，侵襲性歯周炎の原因菌として注目されている Actinobacillus actinomycetemcomitans（A. a）の迅速検出 法を開発した，方法：まず，A. a の標的遺伝子の塩基配列を基に，A． a に特異的なプライマーを設計し，特異性お よび検出感度の評価を行った．さらに，歯肉縁下プラーク等の口腔内試料から A. a の検出を行った。鋳型 DNA は恒 温で反応後, アガロースゲル電気泳動法および SYBR Green I の添加による目視により解析した.

A. a の特異プライマーは，A. a（血清型 a , b , c , d ，および e ）の目的遺伝子を特異的に増幅した. また，4 種類のプライマーに加え，ループプライマーを用いることで検出時間が大幅に短縮された. さらに，歯肉縁下プラー クなどの口腔内試料からあ迅速検出が可能であった．更にリアルタイム濁度測定を行うことにより定量解析あ可能で あった．以上の結果から，LAMP 法が A. a による侵襲性歯周炎の迅速診断法として有用であることが示唆された。

Rapid detection of Actinobacillus actinomycetemcomitans using by Loop-mediated Isothermal Amplification method

Ryo Osawa, Akihiro Yoshida, Shiori Nagashima, Toshihiro Ansai and Tadamichi Takehara (Division of Community Oral Health Science, Kyushu Dental College)

Actinobacillus actinomycetemcomitans has been implicated in the etiology of aggressive periodontitis. In this study, we developed a novel nucleic acid amplification method, termed loop-mediated isothermal amplification (LAMP), which amplifies DNA with high specificity, efficiency, and rapidity under isothermal conditions using a set of four specially designed primers and a DNA polymerase with strand 
displacement activity. To begin with we designed the primers for LAMP assays to detect $A$. actinomycetemcomitans and evaluated the specificities and sensitivities of $A$. actinomycetemcomitans. The specificities of the primers for A. actinomycetemcomitans were examined using chromosomal DNA of various oral bacteria. The sensitivities of $A$. actinomycetemcomitans were examined using agarose gel electrophoresis. Furthermore, LAMP assays were made use of for the rapid detection of $A$. actinomycetemcomitans in clinical specimens from 10 individuals. The LAMP primers used in this study successfully amplified the a to e serotypes of A. actinomycetemcomitans, while other oral bacteria were not amplified. The detection limits using real-time turbidimetry analysis were 10 to $10^{6}$ copies for $A$. actinomycetemcomitans template DNA in one reaction tube. Also, the results for the LAMP method closely agree with those using conventional PCR. Our results suggest that LAMP-based assay is very useful for the rapid detection of A. actinomycetemcomitans and the diagnosis of aggressive periodontitis.

\section{4. 加齢に伴うロ腔の立体認知能の低下ー摂食機能リハビリテーションに関する基礎的研究}

○河岸 重則 ${ }^{1} \cdot$ 神 房次 ${ }^{2} \cdot$ 吉野 賢一 $^{1} \cdot$ 鱒見 $\quad$ 進一 $^{3} \cdot$ 天野仁一朗 ${ }^{1}$

${ }^{1}$ 九歯大·摂食科学, ${ }^{2}$ 神歯科医院, ${ }^{3}$ 九歯大·尔損再構築

北九州市小倉北区の軽費老人ホーム居住の高齢者 40 名と九州歯科大学学生 175 名を対象に口腔の立体認知能を調 查した。調查では被験者に口腔に含んだ 20 種類マテリアルの形状を判断させた. 学生群の平均正答数は 16.6 種, 高齢 者群の平均正答数は 10.5 種であった. 20 種のマテリアル各々に対する高齢者群の平均正答率は, 全てのマテリアルで 学生群の正答率より低かった。 また， 80 歳代の高齢者 4 人を対象にして，トレーニングで正答数が上がるが゙うかを 検討した． 3 日招きに，基本的な形状の 6 種のマテリアルと正答率の低い 8 種のマテリアルについて，その形状をロ 腔内で判断するトレーニングを計 10 日間の行ったところ，3名に正答数の上昇の傾向がみられた。

\section{The effects of aging on oral stereognostic ability}

Shigenori Kawagishi ${ }^{1}$, Fusaji Kou ${ }^{2}$, Kenichi Yoshino ${ }^{1}$, Shin-ichi Masumi ${ }^{3}$ and Niichiro Amano ${ }^{1}\left(^{1}\right.$ Division of Oral Neuroscience, Kyushu Dental College, ${ }^{2}$ Kou Dental Clinic and ${ }^{3}$ Division of Occlusion \& Maxillofacial Reconstruction, Kyushu Dental College)

The oral ability to recognize the form of objects was examined. 175 young (avg. 24.5 years old) and 40 old subjects (avg. 78.8 years old) assessed the form of twenty kinds of objects with and without palatal coverage. No effects of palatal coverage on the ability under study were detected. The old subjects had reduced ability to identify form: the percentages of correct answers for young and old subjects were about $83 \%$ and $53 \%$, respectively. Subsequently, four old subjects in their eighties practiced recognizing the form of objects orally every 3 days for one month. The percentages of correct answers showed a rising trend for the three subjects.

\section{5．要介護高齢者の唾液电糸性に対する音波歯ブラシの効果}

○柿木 保明·服部 信一·尾崎 由衛 九歯大·摂食少八

要介護高齢者の口腔乾燥度改善に関する検討として, 音波菌ブラシ SONICARE の使用による唾液或系性の变化に ついて検討した. 対象は, 佐賀県内の老人保健施設に入所中の 65 歳 99 歳の要介護高齢者 36 名とした. 対象者に対 して, 歯科衛生士が, 週 3 回で計 4 週間, 音波歯ブラシの植毛部の裏側を用いて, 両側の㚘粘膜と舌の左右辺縁部後 方部の 4 力所を, 1 䇢所につき 10 秒ずつ, 計 40 秒間マッサージを行い, 有歯顎者には, 引き続き歯磨きを行った. 口腔乾燥度の評価は, 柿木が報告した臨床診断基準を用いて評価し, 唾液曳系性は, 井上鉄工所製の曳糸性測定器ネ バメーターにより，安静時唾液をWet Mode で測定した。これらの評価は，原則として午前 10 時から 11 時の間と し，30 分以上，水分や食事を摄取していないことを確認して行った。 その結果，臨床診断基準では，4 週後， 6 週後 になるにしたがって，乾燥度の低下を示す者が有意に（p<0.01）に增加した．唾液曳糸性は，36 名中 16 名が測定可 